\title{
THE TREATY-MAKING POWER OF THE GOVERN- MENT OF THE UNITED STATES IN ITS INTERNATIONAL ASPECT
}

In his very interesting book on the United States in the Twentieth Century, M. Leroy-Beaulieu uses the following remarkable language: ${ }^{1}$

The first century following the annexation of Louisiana witnessed the United States obtain a preponderating influence over North America. The centenary of that great event finds the United States expanding beyond the confines of America. Before the second centenary be far advanced the United States will unquestionably dominate economically all the Asiatic and American countries bordering on the Pacific, and will be playing in the world the part played until these latter days by England.

This prediction is certainly gratifying to American pride. If it is ever to be realized, its fulfilment must rest upon the basis of national power and national good faith. The United States must realize that it is a nation, that it has the power of a nation, and is subject to the responsibilities of this power. Yet, surprising as it may seem, the fact is undoubted that within a few years, and, indeed, from time to time throughout our national existence, citizens of the United States and of foreign countries as well, who had at least for a time the public ear, have maintained that there was no sanction to a treaty made by the United States, and no national power capable of enforcing its provisions within the Federal limits. The question was raised most recently in reference to the admission of Japanese children to the public schools of San Francisco. It has, however, been discussed in every decade since the Republic came into being. Never did it have more importance than at the present moment. My object in this paper is to maintain that a treaty, when made by the President of the United States and ratified by the Senate, is binding upon every resident of the United States and every citizen of the Republic wherever he may be, and that the President and the Federal Courts are vested with power to enforce the provisions of the treaty, and that it is the duty of Congress to pass all laws which may be necessary to carry these provisions into effect.

Since this is an International Association, it surely cannot be out of place to call attention to the historic character of the American

r. Introduction, p. xxvi. 
Constitution. The War of the American Revolution, as Lord Beaconsfield long ago pointed out, was not a war for freedom but for independence. The rights which the English colonists brought with them from Great Britain they retained. A strong spirit of personal freedom was developed by the conditions of life in the New World, and led finally to an impatience of restraint from the British Parliament. The war came, and at its close the British Government recognized the independence of the thirteen colonies. These had prosecuted the war under a confederacy which possessed few national powers. The treaty of peace concluded at Paris, September $3^{\text {rd, }} \times 783$, contained in its first article the following clause:

His Britannic Majesty acknowledges the said United States, viz., New Hampshire, Massachusetts Bay, Rhode Island and Providence Plantations, Connecticut, New York, New Jersey, Pennsylvania, Delaware, Maryland, Virginia, North Carolina, South Carolina, and Georgia.

As soon as the cohesive power which the necessities of war had exercised ceased to exist, the colonies began to realize that something more substantial was necessary to enable them to exist as a nation. A convention was called. A Constitution was adopted and submitted to the States for ratification. The preamble of this instrument declares that "We the people of the United States, in order to form a more perfect union . . . do ordain and establish this Constitution for the United States of America." To use the language of our greatest constitutional lawyer, Daniel Webster:-

The Constitution itself declares that it is ordained and established by the people of the United States. . . . It is in this their collective capacity, it is as all the people of the United States, that they establish the Constitution. ${ }^{2}$

One of the distinctive features of this new government as compared with the old confederacy was that it vested the executive power in the President, the judicial power in one Supreme Court and in such inferior courts "as Congress may from time to time ordain and establish," and certain legislative powers, which are specified, in a Congress. In the article relating to the executive power it is provided that the President "shall have power, by and with the advice and consent of the Senate, to make treaties, provided two-thirds of the Senate as present concur." (Article 2, Section 2.)

In the article relating to the powers of Congress, certain restrictions upon the powers of the States are contained. Section ro provides: "No State shall enter into any treaty, alliance, or confedera-

2. Webster's Works, vol. iii, p. 346 . 
tion." It is evident from this statement, and certainly words could not be plainer, that the controversy that has often arisen in the United States as to whether particular powers are conferred upon the general government or reserved to the States respectively does not exist in reference to the treaty-making power. This is expressly conferred in positive terms upon the Executive of the United States, and is expressly denied, in words equally positive, to the several States. The framers of the Constitution evidently intended that on this point at least there should be no possible controversy. Accordingly, in the sixth article, we find the following provision, subdivision $2:-$

This Constitution and the laws of the United States which shall be made in pursuance thereof; and all treaties made or which shall be made under the authority of the United States shall be the supreme law of the land; and the judges in every State shall be bound thereby, anything in the Constitution or laws of any State to the contrary notwithstanding.

The effect of these provisions has never been better stated than by our present Secretary of State, Mr. Root, in his address as President of the American Society of International Law at the first meeting of that body in April last: ${ }^{3}$ -

Legislative power is distributed; upon some subjects the national legislature has authority; upon other subjects the State legislature has authority. Judicial power is distributed; in some cases the Federal Courts have jurisdiction. In other cases the State Courts have jurisdiction. Executive power is distributed; in some fields the national executive is to act; in other fields the State executive is to act. The treaty-making power is not distributed; it is all vested in the National Government; no part of it is vested in or reserved to the States. In international affairs there are no States; there is but one nation, acting in direct relation to and representative of every citizen in every State. Every treaty made under the authority of the United States is made by the National Government as the direct and sole representative of every citizen of the United States residing in California equally with every citizen of the United States residing elsewhere. It is, of course, conceivable that, under pretence of exercising the treaty-making power, the President and Senate might attempt to make provisions regarding matters which are not proper subjects of international agreement, and which would be only colorable-not a real-exercise of the treaty-making power; but so far as the real exercise of the power goes there can be no question of State rights, because the Constitution itself, in the most explicit terms, has precluded the existence of any such question.

Another distinctive feature of the Government which has been established by the American Constitution is the power conferred by it upon courts of justice to declare with authority that a legislative act is void because in violation of some provision of the organic law.

3. American Journal of International Law, vol. i, p. 278. 
The courts of America on the whole have exercised this great power with moderation. But they have continuously exercised it from the foundation of the Government. The language that has been already quoted would seem to be clear. The practice under it has never been better stated than by Mr. Webster himself :-

The judicial power under the Constitution of the United States was made co-extensive with the legislative power. It was extended to all cases arising under the Constitution and the laws of Congress. The Judiciary became thus possessed of the authority of deciding in the last resort, in all cases of alleged interference between State laws and the Constitution and laws of Congress. Gentlemen, this is the actual Constitution, this is the law of the land.

When therefore anyone seeks to understand the exact character of the American Constitution it is necessary that he should study, not only the text of that instrument, but the decisions of the courts which have expounded it. Mr. Webster's lasting title to the gratitude of his countrymen is that he had the genius to perceive the principles of construction upon which alone a written Constitution could become a workable instrument. He had also the power of forensic argument which enabled him to state these principles with such clearness and such convincing force that the judges of the Supreme Court, and notably Mr. Chief Justice Marshall, adopted them and embodied them in the leading cases to which the student of American Constitutional Law must always resort.

On the subject of the force and effect of treaties this great tribunal has spoken with no uncertain sound. In the case of Ware $v$. $H y l t o n$, decided in $1796,{ }^{\circ}$ it had under consideration a controversy which had arisen in Virginia. A law of that State, passed at the time of the Revolution, had confiscated debts which were due from citizens of Virginia to British subjects. The treaty of peace which was adopted in 1783 contained an agreement that creditors on either side "shall meet with no lawful impediment to the recovery of the full value in sterling money of all bona fide debts heretofore contracted." A British subject brought an action in the Federal Court for the district of Virginia to recover a debt from a citizen of Virginia. The Supreme Court held that the treaty of 1783 had, as it were, repealed this statute of Virginia and deprived it of all effect; that this treaty had been, as it were, reaffirmed by the people of the United States when they adopted the Constitution in I789, and had been declared in the clause relating to all treaties to be the supreme

4. Webster's Works, vol. i, p. 209.

5. 3 Dallas Reports, 199. It deserves note that John Marshall was of counsel in this case, p. 210. 
law of the land, and that consequently the courts were bound to enforce it, even though it was retroactive in its character.

Since the decision in Ware v. Hylton, controversies have arisen in reference to the title to land in different States composing the American Union. In 1812, in Fairfax v. Hunter, ${ }^{\circ}$ the Supreme Court held that title to land in Virginia was vested in a British subject by the treaty of 1783 , and that it superseded the laws of Virginia on this subject so far as they were inconsistent with it. Again, in 1817 , in Chirac v. Chirac, ${ }^{7}$ a similar ruling was made in regard to the title of a French subject to land in the State of Maryland. It is true that the courts of this country in considering the effect, not only of treaties but of the provisions of the Constitution itself, have uniformly declared that, in order to justify the court in declaring a particular statute invalid, the contradiction between it and the Constitution or the treaty must be clear.

In the very recent case of Johnson v. Browne, decided April 8th, 1907,8 the judgment of the court on that subject is thus expressed (p. $3^{21}$ ) :-

A later treaty will not be regraded as repealing an earlier statute by implication, unless the two are absolutely incompatible and the statute cannot be enforced without antagonizing the treaty.

Another interesting instance of the application of the rule established by the Supreme Court upon this subject is to be found in what are known as the Passenger Tax Cases. ${ }^{9}$ In these cases statutes had been adopted by the States of New York and Massachusetts imposing a tax upon passengers coming into the ports in those States. The proceeds of the tax thus imposed were used to defray the expense of immigration stations which then were maintained by the States themselves. These acts were alleged to be invalid on several grounds, among these on the ground that they were in conflict with the treaty between the United States and Great Britain. This "contention was sustained by the Supreme Court. ${ }^{10}$ It held:-

3. That the Acts of Massachusetts and New York in question in these cases conflict with treaty stipulations existing between the United States and Great Britain, permitting the inhabitants of the two countries "freely and securely to come, with their ships and cargoes, to all places, ports, and rivers in the territories of each country to which other foreigners are permitted to come, to enter into the same, and to remain and reside in any parts of said

6. 7 Cranch Rep., 603.

7. 2 Wheaton Rep., 259.

8. 205 U. S., 309.

9. 7 Howard, U. S. Reports, 288.

10. 7 Howard, U. S. Reports, 4I2. 
territories respectively; also, to hire and occupy houses and warehouses for the purposes of their commerce, and generally the merchants and traders of each nation respectively shall enjoy the most complete protection and security for their commerce, but subject always to the laws and statutes of the two countries respectively:" and that said laws are therefore unconstitutional and void.

At a later period, when by the Treaty of Paris, Porto Rico was ceded by Spain to the United States, the question arose as to whether that island became, by virtue of the treaty, without any legislation by Congress, territory of the United States, and therefore not foreign. If so, the tariff laws of the United States would cease to apply, and goods coming from Porto Rico to the United States would be entitled to admission free of duty, until Congress should otherwise enact. The Supreme Court so held.11

It will thus be seen that in numerous instances in which personal rights, the title to real estate, the payment of debts, and the imposition of tariff duties are concerned, the provisions of the Constitution on this subject have been enforced by the Federal Courts and the treaty has been carried into effect by them, without further legislation.

Whether the courts will do this or not depends first upon whether the treaty itself provides that further legislation must be had before it shall take effect. Such was the treaty of 1883 with Mexico. ${ }^{12}$ Several treaties with Great Britain have been drawn so that certain portions of them should not take effect until reciprocal legislation should be had, both in the United States and in the Dominion of Canada. In this connection it should be noted that the Legislature of Great Britain takes no part in the ratification of a treaty. Under the Constitution of that country a treaty is negotiated by the Sovereign alone. But this means, of course, so far as Great Britain is concerned, that it is negotiated by his Ministers, who are responsible to Parliament, and who are generally in a position to carry successfully through Parliament any legislation which may be necessary to enforce the stipulations of the treaty. Experience has shown, however, that it does not at all follow that the Legislatures of the different self-governing colonies forming part of the British Empire will approve treaties negotiated by the Home Government, or adopt the laws necessary to carry them into effect.

In the next place it must be remembered that some provisions in treaties can never become the subject of adjudication by the courts.

I1. De Lima v. Bidwell, 182 U. S. I.

12. U. S. Treaties and Conventions, ed. 1889, p. 714. 
The enforcement of these provisions, from the necessity of the case, depends upon the good faith of the Government.

The rule on this subject is well stated by the Supreme Court of the United States in ex parte Cooper, I43 U. S. Reports, 472. This was a case involving the jurisdiction of the United States over the waters of Behring Sea. At page 50I the Supreme Court refers with approval to a previous decision in United States $v$. Rauscher (rrg U.S. 407, 418), as follows:-

Mr. Justice Miller, delivering the opinion of the court, quoted from the Head-Money cases, II2 U. S. 580 , the following language as determinative of the principle upon which the court proceeded: "A treaty is primarily a compact between independent nations. It depends for the enforcement of its provisions on the interest and the honor of the Governments which are parties to it. If these fail, its infraction becomes the subject of international negotiations and reclamations, so far as the injured party chooses to seek redress, which may in the end be enforced by actual war. It is obvious that with all this the judicial courts have nothing to do and can give no redress. But a treaty may also contain provisions which confer certain rights upon the citizens or subjects of one of the nations residing in the territorial limits of the other, which partake of the nature of municipal law, and which are capable of enforcement as between private parties in the courts of the country. An illustration of this character is found in treaties which regulate the mutual rights of citizens and subjects of the contracting nations in regard to rights of property by descent or inheritance, when the individuals concerned are aliens. The Constitution of the United States places such provisions as these in the same category as other laws of Congress, by its declaration that 'this Constitution and the laws made in pursuance thereof, and all treaties made, or which shall be made, under authority of the United States, shall be the supreme law of the land.' A treaty, then, is a law of the land, as an Act of Congress is, whenever its provisions prescribe a rule by which the rights of the private citizen or subject may be determined. And when such rights are of a nature to be enforced in a court of justice, that court resorts to the treaty for a rule of decision for the case before it as it would to a statute."

The question then naturally arises: Are there no limits to the treaty-making power of the President and Senate of the United States? The fundamental rule for the construction of grants of power in the United States Constitution was established by the Supreme Court in Gibbons v. Ogden. There the court had occasion to pass upon the question whether different States of the Union had power to impose taxes or restrictionis upon commerce entering their ports from other States of the Union. In this particular instance the State of New York, in order to reward Robert Fulton and Robert $R$. Livingston for inventions which had made navigation by steam practicable, gave to them and their heirs a monopoly of trade by steam vessels within the waters of the State of New York. 
The Supreme Court held that this grant was in violation of the Constitution of the United States and of the clause in that instrument which confers upon Congress "power to regulate commerce with foreign nations and among the several States." In disposing of this controversy the Supreme Court used the following language: ${ }^{13}-$

The subject is transferred to Congress, and no exception to the grant can be admitted which is not proved by the words or the nature of the thing.

In the Constitution itself there is no restriction in words upon the treaty-making powrer. No doubt some restriction is to be implied from the nature of the case. A treaty with a foreign Government must of necessity relate to some matter which is a proper subject of international regulation. It could not, for example, be contended that it would be competent for the United States to make a treaty with France or Germany by which, in contravention of the laws of the several States of the Union, it should be provided that the suffrage should be conferred upon citizens of the foreign country immediately upon their entering the United States. To use again the language of the Supreme Court in the case of De Geofroy $v$. Riggs:14-

The treaty-power, as expressed in the Constitution, is in terms unlimited except by those restraints which are found in that instrument against the action of the Government or of its departments and those arising from the nature of the Government itself and of that of the States. It would not be contended that it extends so far as to authorize what the Constitution forbids, or a change in the characer of the Government or in that of one of the States, or a cession of any portion of the territory of the latter without its consent. But with these exceptions it is not perceived that there is any limit to the questions which can be adjusted touching any matter which is properly the subject of negotiation with a foreign country.

It will be evident from what has been said that the courts of the United States on this subject have spoken with no uncertain sound. Nor can there be any question under the Constitution of the United States that it is both the power and the duty of the President to enforce the provisions of treaties which have been lawfully ratified by the Senate. Article 2, Section 3 of this instrument provides: "He (the President) shall take care that the laws be faithfully executed." The power is co-extensive with the grant.

There is one limitation, however, to which attention must be drawn. At an early period of our judicial history it was held that in criminal jurisprudence there was no common law of the United

13. 9 Wheaton, 2 I5.

14. 133 U. S., 258. 
States which could be enforced by indictment in the Federal Courts. ${ }^{15}$ In the States, however, it was held that the principles of the English common law had been adopted by them not only in matters of civil but of criminal jurisprudence.

It would have been in the public interest if the Federal Courts had held that, in the absence of special legislation prescribing a different penalty, the violation of an Act of Congress or of a treaty made by the President and ratified by the Senate should constitute a misdemeanor indictable in the Federal Courts and punishable by fine and imprisonment. Such a rule would have enabled the courts of the Union to give effect to the provisions of treaties by indictment as well as by civil suit. Congress, however, has power to enact legislation which shall enable the Federal Courts to punish by indictment a violation of the rights of aliens conferred by treaty. This was expressly held by the Supreme Court in Baldwin v. Franks:18-

That the United States have power under the Constitution to provide for the punishment of those who are guilty of depriving Chinese subjects of any of the rights, privileges, immunities, or exemptions guaranteed to them by this treaty we do not doubt.

The remaining question to which I desire to draw your attention relates to the duty of Congress in reference to the enforcement of the provisions of a treaty. For example, when a treaty provides for the payment of money by the United States in satisfaction of the claims of foreign subjects, what is the position of Congress in the matter? The controversy on this subject first arose in reference to the provisions of the treaty negotiated by John Jay, the first Chief Justice of the United States, during President Washington's administration. This treaty provided for the payment by the United States to British subjects of an indemnity for certain wrongs which had been inflicted upon them. The treaty was ratified by the Senate. A bill was introduced in the House of Representatives to provide for the payment. It is obvious that in all free Governments it is an essential condition that money shall be appropriated from the treasury and paid out by the fiscal officers, only in obedience to an act of the Legislature. On this ground it was contended that the House of Representatives was not bound to give effect to the provisions of the treaty. Party feeling ran high. War was then raging between France-the old friend of the American Republic-and Great Britain. Many Americans sympathized with France. The

15. United States v. Hudson, 7 Cranch Reports, 32 (1812).

I6. I20 U. S. 679. 
feeling of gratitude for the aid rendered by France in the war of the Revolution was strong. It is not surprising that many Americans should have felt it wrong to do anything which might be construed as giving aid and comfort to Great Britain under such circumstances. The historic argument on this subject was made by a member of Congress from Massachusetts, Fisher Ames. He was one of the leading men of his time. His works have been collected in two volumes. Everything else that he wrote will probably be forgotten, except by the antiquarian, but his appeal on this subject is a masterpiece, and has the almost unique distinction of having excited such emotion in members of Congress who heard it that one of the Opposition rose at its conclusion and moved that the vote might be postponed, in order that members might not cast their votes too much under the influence of the speech. It was successful, however, and its arguments are just as convincing to-day as they were in 1796 . After showing that under the Constitution the House of Representatives had no part in the making of the treaty or in its ratification, he goes on to say: ${ }^{17}$ -

A treaty is a bargain between nations binding in good faith. And what makes a bargain? The assent of the contracting parties. We allow that the treaty-power is not in this House. This House has no share in contracting, and is not a party. In consequence the President and Senate alone may make a treaty that is binding in good faith.

If we choose to observe it with good faith our course is obvious. Whatever is stipulated to be done by the nation must be complied with. Our agency, if it should be requested, cannot be properly refused, and I do not see why it is not as obligatory a rule of conduct for the Legislature as for the courts of law.

And then he warns the House, and the warning is just as much needed to-day as it was a century ago:-

Objections that proceed upon error in fact or calculation may be traced and exposed. But such as are drawn from the imagination, or traced to it, return to domineer over the mind after having been banished from it by truth.

And he adds:

If both parties be not obliged, neither is obliged. It is no compact, no treaty. This is the dictate of law and common sense, and every jury in the country has sanctioned it on oath. It cannot be a treaty yet no treaty, a bargain and yet no promise. If it is a promise, I am not to read a lecture to show why an honest man will keep his promise. . . . No less impossible that we should desire to assert the scandalous privilege of being free after we have pledged our honor.

17. Fisher Ames Works, vol. 2, pp. 43, 44, 47. 
I regret to say that the United States have not always been loyal to the principles thus stated. There are instances in American listory in which Congress has failed to pass laws necessary to enforce or protect rights conferred by treaties which have been lawfully made and have therefore become the supreme law of the land. Such failure is a just cause of complaint by the foreign Power, and every true American should see to it, so far as in him lies, that no such failure occur in the future.

One other proposition in this connection remains to be considered. The Constitution of the United States, as has been shown, declares that the treaty is the supreme law of the land. In one of the ablest arguments that was ever made by that great advocate who now is chairman of the delegation from the United States to the second Hague Conference, Mr. Choate, he contended that this clause meant that the treaty once made could only be changed by the same power that made it, that is to say, by the President, with the advice and consent of the Senate. This contention did not prevail. In the Chinese Exclusion Cases, ${ }^{18}$ the Supreme Court of the United States felt itself obliged to hold that however just might be the grievance to a foreign nation, even amounting, as was conceded, to a casus belli, yet the treaty had no greater force than an Act of Congress, and, consequently, that an Act of Congress could change it. This, after all, is holding that it is within the power of a nation to violate its solemn obligations. Such power exists, and must be reckoned with. But the obligation of honor and duty remains. To inculcate this obligation is a part of that campaign of education which William L. Wilson declared was, in a country of universal suffrage, a continuing duty.

Everett $P$. Wheeler.

18. Fong Yue Ting v. United States, I49 U. S. 698. 